\title{
Decrease in the photosynthetic rate of leaves of Ilex rotunda seedlings exposed to urban atmospheric condition
}

\author{
Takagi, Masahiro ${ }^{1,2}$ and Gyokusen, Koichiro ${ }^{1}$
}

\begin{abstract}
In order to quantify the sole effect of urban atmospheric condition on revegetation trees, we exposed potted $I$. rotunda seedlings in the central district of Fukuoka City, where air pollutant concentration was high and heat island effect was observed, and in a suburban nursery as control. The seedlings of both sites were subjected to identical sunlight and soil conditions. After 10-week exposure, we observed a significant reduction of the photosynthetic rate of leaves, but not of growth. The reduction of photosynthetic rate would be caused by highly concentrated air pollutant as well as heat island effect. The reduction was due to the reduced carboxylation efficiency and was moderated by the soil of higher nitrogen content.
\end{abstract}

Key words: air pollutant, heat island effect, Ilex rotunda, photosynthesis, exposure experiment

高木正博・玉泉幸一郎：都市内の大気環境への暴露によって低下したクロガネモチ苗木の光合成速度

摘要：都市環境が緑化樹に与える様々なストレス要因のうち, 車が集中する都市部で必然的に悪化する大気環境 （高い大気污染物質濃度とヒートアイランド効果）の影響を知るために, 福岡市の中心部とコントロールとして $5 \mathrm{~km}$ 離れた郊外にクロガネモチの鉢苗を 10 週間暴露した。暴露処理中は暴露個体とコントロールで同じ土壤水 分条件と光環境を保った。暴露処理の後, 単葉の光合成速度は暴露個体で有意に減少したが成長は差が認められ なかった。この光合成速度の低下の原因として, 高い濃度の大気污染物質濃度の影響だけではなくて高い気温と 低い湿度といったヒートアイランド効果の影響も考えられた。光合成速度の減少は, 気孔の阻害よりも二酸化炭 素固定効率の低下によってもたらされていた。また土壤中窒素濃度が高いと光合成速度の低下は緩和された。 キーワード : 大気污染物質，ヒートアイランド効果，クロガネモチ，光合成，暴露実験

\section{Introduction}

Revegetation trees grown in urban areas suffer from many and concurrent environmental stresses, such as air pollutant, air of higher temperature and lower humidity, diminished sunlight, and poor nutrient and tread soil. The stresses were realized as decrease in growth and depression of physiological activities (Mansfield \& Freer-Smith, 1981; Jim, 1992; Hodge \& Boswell, 1993). The decrease in growth rate and chlorophyll content of revegetation trees in urban area compared to suburban was reported for Ligustrum lucidum (Cañas et al., 1997) and for Delonix regia and Cassia fistula (Pandey \& Agrawal, 1994). The lowered photosynthetic rate of Tilia euchlora and Elaeagnus angustifolia in urban area was indicated by Gej \& Gozlinski (1983).

Of the many stress factors affecting revegetation trees due to urbanization, atmospheric factors (i.e., air pollutants, higher temperature and lower humidity) are inherent in urbanization. Air pollutant concentration is necessarily higher in the districts with high vehicular traffic. Temperature and humidity of air are affected by waste heat and heat radiated from concrete surfaces (heat island effect). In contrast, stresses caused by insufficient sunlight due to interception by surrounding buildings and poor soil condition could be improved by planning planting position or adequate arboricultural management. Therefore, it is important to separate and quantify the effect of atmospheric factors from that of the remediable factors, in order to investigate the cause of decrease in growth and depressed physiological activity of revegetation trees. This would be also useful in urban planning and selecting revegetation tree species.

The maximum photosynthetic rate of mature Ilex rotunda Thunb. in the central district of Fukuoka was lower than that of suburban I. rotunda (Takagi et al., 1996), although $I$. rotunda is known to be tolerant to air pollutants and poor sunlight condition. This depression is likely to be caused by the atmospheric stress factor, because the concentration of air pollutant in the district was extremely high (Statistical Bureau of the City of Fukuoka, 1995) and heat island effect was observed (Takagi et al., 1996). In this study, we grew potted $I$. rotunda seedlings in the central dis-

\footnotetext{
${ }^{1}$ Graduate School of Agriculture, Kyushu University, 九州大学農学研究科

${ }^{2}$ Present address: Miyazaki University Forests, 宮崎大学農学部附属自然共生フィールド科学教育研究センター
} 
tricts of Fukuoka and in a control suburban site under identical sunlight and soil conditions to investigate the sole effect of atmospheric stress factor, eliminating remediable stress factors. After a 10-week exposure, we compared the growth and photosynthesis capacity of the seedlings.

\section{Materials and methods}

\subsection{Plant material}

I. rotunda is a board-leaved evergreen tree, the major urban revegetation tree species in Fukuoka and was chosen as the city tree. Two-year-old commercially available seedlings of $I$. rotunda were planted in 3.3 L volume ceramic pots containing a 7:3 mixture of granite clay and porous gravel (Kanumatsuti). All seedlings were grown outdoors in the nursery of the Kyushu University for three months from mid April 1997. The nursery was in a suburban areas of the city, $1 \mathrm{~km}$ from heavy traffic streets and thus free from car exhaust. Watering was carried out as necessary. Granulated fertilizer (JA, Kumiai urea containing IB Kasei No. S1), which is effective over a few months, was supplied to half of the seedlings at planting at $2 \mathrm{~g}$ nitrogen per pot. The remaining seedlings were not supplied with the additional fertilizer. On 13 July, after measuring stem size and photosynthetic rates, the seedlings of both fertilizing groups were divided into exposure and control treatment respectively, so that the average photosynthesis rate for both treatment was almost equal. The half of the seedlings subjected to the exposure treatment were transferred to the central districts of the city described below. The remaining seedlings were allowed to continue growing in the nursery as control. Four sets of the seedlings were thus obtained, consisting of five seedlings each.

2.2 Study site and exposure treatment

The transferred seedlings were exposed to urban atmospheric conditions for 10 weeks at a median strip in the central district of Fukuoka, $5 \mathrm{~km}$ south from the nursery. Fukuoka $\left(33^{\circ} 35^{\prime} \mathrm{N}, 130^{\circ} 24^{\prime} \mathrm{E}\right)$ is the central commercial city in western Japan and has a population of 1.2 million. The street runs north to south, is 45 $\mathrm{m}$ in width with six lanes, and is situated between buildings of 30 to $40 \mathrm{~m}$ in height. Traffic flow over a 12 $\mathrm{h}$ daytime period on the street was 30,000 cars. The pots were placed in an open space on the southern edge of the median strip. At this median strip, the duration of direct sunlight irradiating the seedlings was restricted by buildings on the east and west. In order to obtain irradiation time equal to that in the central district, we hung shading sheets on the west and east sides of the seedlings in the nursery.

During exposure, water of the same quality and quantity was given to the exposed and the control seedlings every day except on rainy days. Concentrations of $\mathrm{NO}_{2}$ and $\mathrm{SO}_{2}$ were measured since these gases were directly exhausted from cars. Mean $\mathrm{NO}_{2}$ and $\mathrm{SO}_{2}$ concentrations for $24 \mathrm{~h}$ were measured using a passive $\mathrm{NO}_{2}$ and $\mathrm{SO}_{2}$ sampler (Green blue, Handy SONOx) three times at weekly intervals. Temperature and humidity of the air were recorded using a temperature and humidity probe and recorded at 10-min intervals (Sato Keiryoki, SKL-2000TH) during the exposure. The diurnal course of PAR for both the exposed and the control seedlings were measured using the PAR sensors (Koito Industries, IKS-25) on 20 August. These sensors and samplers were set just above the seedlings. On 23 September, seedlings were transferred to the laboratory of the Kyushu University for growth and photosynthesis measurements and chemical analysis.

\subsection{Measurement of seedling properties}

The photosynthesis rate $(P)$ of leaves of the seedlings was measured before and after the exposure using a portable photosynthesis and transpiration measurement system (ADC, LCA-3). Before the exposure, $P$ for three leaves per seedling was measured in the nursery under full sunlight at ambient $\mathrm{CO}_{2}$ concentrations. Following the exposure, the response of $P$ to varying $\mathrm{CO}_{2}$ concentration under light saturated condition were measured with a single leaf attached to the seedling. Three leaves per seedling, three seedlings per treatment for a total of nine leaves per treatment were measured. The $\mathrm{CO}_{2}$ concentration supplied to the leaves was controlled by a mass flow valve that mixed pure $\mathrm{CO}_{2}$ gas gasified from liquid $\mathrm{CO}_{2}$ and $\mathrm{CO}_{2}$-free air passed through soda lime. Leaf temperature was measured with a thermistor in a chamber and maintained at $25 \pm 0.5^{\circ} \mathrm{C}$ by a peltier element optionally attached under the chamber. Light was provided by a metal halide lamp (OSRAM, HQI-TS 70W/NDL) and set to $1,200 \mu \mathrm{mol} \mathrm{m}{ }^{-2} \mathrm{~s}^{-1}$ in PAR. Humidity was set to $1.3 \pm 0.1$ $\mathrm{kPa}$ in VPD by turning a valve controlling the humidity of inlet gas to a leaf chamber of the LCA-3.

From the response curve, $P$ and stomatal conductance at $350 \mu \mathrm{mol} \mathrm{mol}{ }^{-1} \mathrm{CO}_{2}$ concentration were used for analysis and called $P_{350}$ and $g_{\mathrm{s} 350}$, respectively. Intercellular $\mathrm{CO}_{2}$ concentration was calculated after von Caemmerer \& Farquhar (1981). The slope of the initial linear portion of the response curve of $P$ to intercellular $\mathrm{CO}_{2}$ concentration was defined as carboxylation efficiency $\left(K_{\mathrm{c}}\right)$ (Farquhar \& Sharkey, 1982). The $P$ was measured under dark and $350 \mu \mathrm{mol} \mathrm{mol}{ }^{-1} \mathrm{CO}_{2}$ concentrations and called dark respiration rate $\left(R_{\mathrm{d}}\right)$. Regulation capacity of stomata $\left(q_{\mathrm{g}}\right)$ was estimated as the ratio of $g_{\mathrm{s} 350}$ to minimal stomatal conductance during dark respiration (Kammerbauer et al., 1987). The effect of the exposure treatment on growth of all seedlings was indicated as the ratio of the increment of the size of stem during the exposure to that of the beginning of the exposure. The stem size $\left(\mathrm{D}_{0}{ }^{2} \mathrm{H}\right)$ was evaluated by the product of the height and squared diameter at soil 
surface. The total nitrogen of the soil in all pots was analyzed after the photosynthesis measurement with 1 g dried soil using a CN corder (Yanako, MT-500). The soils of the each treatments were sampled from the all pots and pooled and mixed for the analysis respectively. Non parametric two-way ANOVA was used to compare each parameter between the exposed and the control seedlings and between the fertilized and the unfertilized seedlings.

\section{Results}

\subsection{Exposure condition}

Daily mean concentrations of $\mathrm{NO}_{2}$ and $\mathrm{SO}_{2}$ were higher in the urban district than in the control nursery. The average $\mathrm{NO}_{2}$ for three measurements was $120( \pm 17$ SE) $\mathrm{nmol} \mathrm{mol}^{-1}$ in the urban district and $30( \pm 2 \mathrm{SE})$ nmol mol${ }^{-1}$ in the nursery. The concentrations of $\mathrm{SO}_{2}$ was $41( \pm 4 \mathrm{SE}) \mathrm{nmol} \mathrm{mol}^{-1}$ in the urban district and $4( \pm 1 \mathrm{SE}) \mathrm{nmol} \mathrm{mol}^{-1}$ in the nursery. The heat island effect was observed in the urban district. The average, minimum and maximum of air temperature during the exposure was higher in the urban district than in the control nursery (Table 1). The average, minimum and maximum of air humidity during the treatment was lower in the urban district than the control nursery. In the urban district, the sunlight irradiated seedlings was for only five hours due to the interception by the surrounding buildings. An identical diurnal course of PAR was obtained at the nursery by hanging shading sheets beside the seedlings (Fig. 1).

Table 1 Average, minimum and maximum of air temperature $\left({ }^{\circ} \mathrm{C}\right)$ and air humidity (\%) in urban district of Fukuoka City and in suburban control district during study period

表-1 試験地と対照区とした郊外の暴露期間中の気温 $\left({ }^{\circ} \mathrm{C}\right)$ と湿度（\%）の最小值，最大值および平均值

\begin{tabular}{lccccc}
\hline & \multicolumn{2}{c}{ Air temperature } & & \multicolumn{2}{c}{ Air humidity } \\
\cline { 2 - 3 } \cline { 5 - 6 } & Urban & Control & & Urban & Control \\
\hline Average & 29.9 & 27.4 & & 62.5 & 75.6 \\
Minimum & 23.4 & 19.1 & & 29.6 & 40.1 \\
Maximum & 41.4 & 37.0 & & 95.6 & 99.9 \\
\hline
\end{tabular}

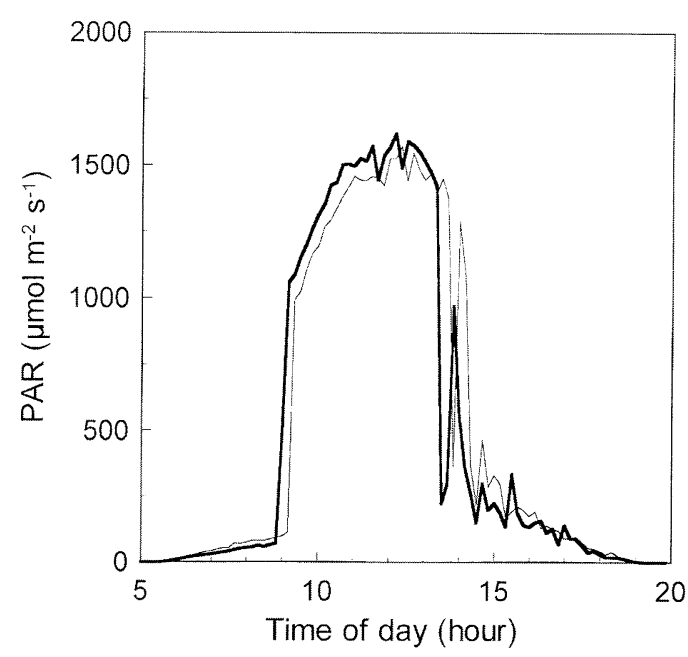

Fig. 1 Diurnal courses of PAR in urban district of Fukuoka City (thin line) and in suburban control site (bold line) on August 27, 1997. The latter was modified by hanging shading sheets beside the seedlings to obtain sunlight conditions identical to those of the urban seedlings.

図-1 1997 年 8 月 27 日における福岡市中心部 (細線) と対照 区とした郊外 (太線) の PAR の日変化

対照区では中心部と同じ日変化を得るために鉢苗の両 側に寒冷紗をぶら下げた。

\subsection{Seedling characteristic}

The average and standard errors of seedling characteristics are shown in Fig. 2. The results of non parametric two-way ANOVA of the seedling characteristics are shown in Table 2. The relative size increment of the stem $\left(\Delta \mathrm{D}_{0}{ }^{2} \mathrm{H}\right)$ did not differ significantly between the exposed and the control seedlings. In contrast, $P_{350}$ and $K_{\mathrm{c}}$ decreased significantly for both fertilized and unfertilized groups due to the exposure to the urban atmosphere. $P_{350}$ decreased by $30 \%$ for the unfertilized group and by $20 \%$ for the fertilized group. The decrease in $K_{\mathrm{c}}$ was by $27 \%$ for both groups. Nitrogen rich soil moderated the decrease in $P_{350}$. $R_{\mathrm{d}}$ differed significantly with exposure and fertilizing treatment, but the interaction was also significant. The effects of the exposure and fertilizing treatment on $g_{\mathrm{s} 350}$ were insignificant and interactive. The $g_{\mathrm{s} 350}$ of the exposed seedlings

Table 2 Probability of $2 \times 2$ factorial analysis for gas exchange parameters and stem size increment of Ilex rotunda seedlings after 10-week exposure to urban atmospheric condition and suburban control condition

表-2 都市大気環境と対照区の郊外に 10 週間暴露したクロガネモチ鉢苗のガス交換特性と成長の暴露処理と施肥処理による二元 分散分析

\begin{tabular}{|c|c|c|c|}
\hline & Exposure & Fertilize & Interaction \\
\hline Photosynthetic rate $\left(P_{350}\right)$ & $p<0.01$ & n.s. & n.s. \\
\hline Calboxylation efficiency $\left(K_{\mathrm{c}}\right)$ & $p<0.001$ & $p<0.01$ & n.s. \\
\hline Dark respiration rate $\left(R_{\mathrm{d}}\right)$ & $p<0.05$ & $p<0.01$ & $p<0.01$ \\
\hline Stomatal conductance $\left(g_{\mathrm{s} 350}\right)$ & n.s. & n.s. & $p<0.01$ \\
\hline Stomata regulation capacity $\left(q_{\mathrm{g}}\right)$ & $p<0.05$ & n.s. & n.s. \\
\hline Stem size increment $\left(\Delta \mathrm{D}_{0}^{2} \mathrm{H}\right)$ & n.s. & $p<0.001$ & n.s. \\
\hline
\end{tabular}

n.s., not significant. 

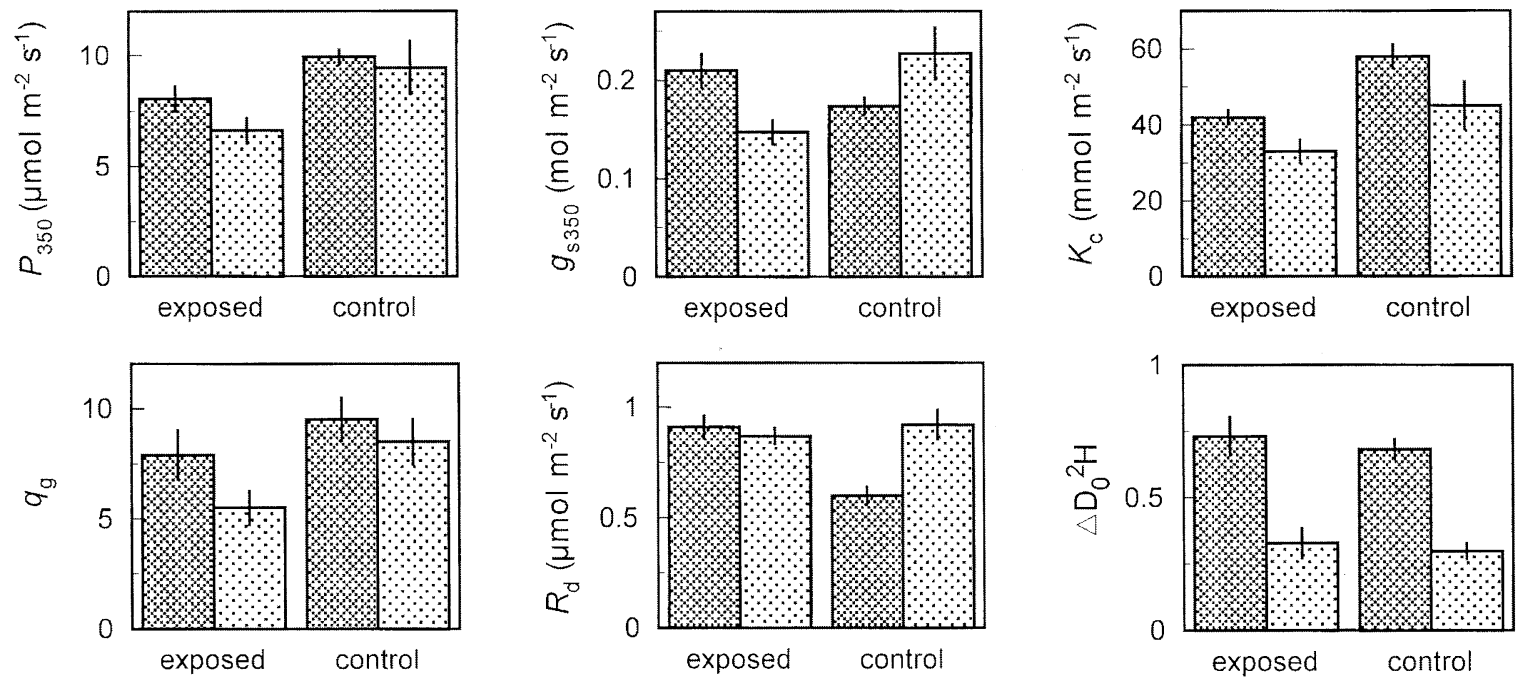

Q. fertilized

unfertilized

Fig. 2 Photosynthetic rate $\left(P_{350}\right)$, carboxylation efficiency $\left(K_{\mathrm{c}}\right)$, dark respiration rate $\left(R_{\mathrm{d}}\right)$, stomatal conductance $\left(g_{\mathrm{s} 500}\right)$, stomata regulation capacity $\left(q_{\mathrm{g}}\right)$ and stem size increment $\left(\Delta \mathrm{D}_{0}{ }^{2} \mathrm{H}\right)$ of fertilized and unfertilized Ilex rotunda seedlings of the urban district (exposed) and of suburban control site (control) after 10-week exposure. Bars indicate standard errors.

図-2 10 週間の暴露期間終了後の暴露個体と対照個体の光合成速度 $\left(P_{350}\right)$, カルボキシル化効率 $\left(K_{\mathrm{c}}\right)$, 暗呼吸速度 $\left(R_{\mathrm{d}}\right)$, 気孔 コンダクタンス $\left(g_{\mathrm{s} 350}\right)$, 気孔開閉能力 $\left(q_{\mathrm{g}}\right)$ および幹成長速度 $\left(\Delta \mathrm{D}_{0}{ }^{2} \mathrm{H}\right)$

縦棒は標準誤差を示す。

was higher in the fertilized groups and lower the in unfertilized groups. The $q_{\mathrm{g}}$ of both the fertilized and unfertilized groups decreased significantly due to exposure.

The total nitrogen concentration of the pooled soil sample of the fertilized group was higher than that of the unfertilized group after exposure. The nitrogen concentrations for the fertilized groups were $0.34 \mathrm{~g} \mathrm{~kg}^{-1}$ and $0.32 \mathrm{~g} \mathrm{~kg}^{-1}$; concentrations for the unfertilized groups were $0.21 \mathrm{~g} \mathrm{~kg}^{-1}$ and $0.20 \mathrm{~g} \mathrm{~kg}^{-1}$, for the exposed and the control seedlings, respectively. These concentrations were lower than that of planting pits of $I$. rotunda in Fukuoka. The range of the concentration of 13 locations throughout Fukuoka was from 0.1 to $2.0 \mathrm{~g} \mathrm{~kg}^{-1}$ (Takagi and Gyokusen, unpublished data).

\section{Discussion}

Exposure to urban air condition for 10 weeks reduced the photosynthetic rate of $I$. rotunda seedlings but did not affect the growth. Depressed photosynthetic capacity of mature trees in urban areas was observed for $I$. rotunda (Takagi et al., 1996) and for Tilia euchlora and Elaeagnus angustifolia (Gej \& Gozlinski, 1983). However, these studies could not determine whether the cause of depression was inherent factors in urbanization (atmospheric conditions) or remediable factors by arboricultural management (sunlight and soil condition). In this study, the effects of the remediable factors on the exposed seedlings were eliminated, and the $P_{350}$ of the exposed seedlings was reduced. Therefore, we could indicate that urban atmospheric conditions alone depressed the photosynthetic capacity of $I$. rotunda.

One reason that the seedling growth was not significantly affected by the exposure but the photosynthetic capacity was reduced might be the short duration of the exposure. Although the $P_{350}$ decreased by $30 \%$ for the unfertilized seedlings and by $20 \%$ for the fertilized seedlings, the $\Delta \mathrm{D}_{0}{ }^{2} \mathrm{H}$ were not significantly different between the exposure seedlings and control. Decreased carbon assimilation, however, should cause decreased mass increment. Therefore, this undisturbed growth irrespective of carbon gain may be the evidence of tolerance to the stresses of I. rotunda.

Both the higher concentration of air pollutant and the heat island effect would be the cause of the decrease in $P_{350}$. Kammerbauer et al. (1987) concluded that the $30 \%$ decrease in photosynthetic rate of Picea abies exposed at a highway border for 10 weeks was due to reduced carboxylation efficiency. Whitlow et al. (1992) observed water deficit of leaves of Tilia cordata and Fraxinus pennsylvanica brought about by the higher air temperature and lower humidity of the urban atmosphere in New York, USA. Water stress reduces carboxylation efficiency (Lambers et al., 1998). However, dry condition can protect plant from air pollution. Lower relative humidity closed stomata thus less ozone was able to enter leaves (Treshow \& Anderson, 1989). Further research will be needed to understand the mechanism of impaired photosynthesis 
by urban atmosphere to revegetation trees.

For the most part of the reduction in $P_{350}$ by the exposure to the urban atmosphere was due to the depressed $K_{\mathrm{c}}$. However, the degree of reduction in $P_{350}$ differed between the fertilizing treatments; $30 \%$ decrease for the unfertilized group and $20 \%$ decrease for the fertilized group, although the degree of reduction in $K_{c}$ did not differ between the fertilizing treatments; $27 \%$ decrease for both groups. Thus the difference of $P_{350}$ between the fertilizing treatments would be due to the difference of stomatal conductance. For the fertilized seedlings, the decreased photosynthetic capacity due to the reduced carboxylation efficiency was moderated by the improved stomatal opening. In contrast, for the unfertilized seedlings, that was accelerated by the reduced stomatal opening. The reason for the differing stomatal behavior with fertilizing treatments was unclear. However, significantly reduced $q_{\mathrm{g}}$ due to the exposure indicated that the urban atmospheric condition was injurious to stomata. Wolfenden \& Mansfield (1991) indicated that guard cells of stomata could be disrupted by $\mathrm{SO}_{2}$ causing stomata to remain open. Hirano et al. (1991) showed that dust that fell into stomata reduced stomatal conductance and prevented stomata from closing.

We did not measure ozone concentration in this study, because we thought that its concentration did not differ between the urban and the control site as distinctly as compared with that of $\mathrm{NO}_{2}$ and $\mathrm{SO}_{2}$ since it is a secondary generated air pollutant. The photochemical oxidant concentration monitored by the City office indicated that differences of its concentration throughout the city were parallel to those of $\mathrm{NO}_{2}$ and $\mathrm{SO}_{2}$ (Statistical Bureau of the City of Fukuoka, 1998). Ozone is known to depress physiological activities of plants. Therefore, ozone might be one of the culprits causing the reduced photosynthetic capacity of the exposed seedlings.

Not only the $P_{350}$ but also in situ photosynthetic rate of the urban exposed seedlings would be lower than those in the nursery. In situ photosynthetic rate is affected by environmental factors. Among these factors, $\mathrm{CO}_{2}$ concentration, air temperature and humidity might not be the same in the urban district and the control nursery. However, Takagi et al. (1998) found that, in spite of having a higher $\mathrm{CO}_{2}$ concentration, the urban district caused reduced in situ photosynthetic rates in mature planted $I$. rotunda compared to the control nursery site due to lower air humidity.

Two suggestions concerning selection of revegetation tree species and their arboricultural management could be derived from this study. First, tolerance to heat island effect as well as air pollution is important as selection criteria of revegetation species. Second, nutritious soil can moderate depression of photosynthetic capacity due to air pollutant.

\section{References}

Cañas, M. S., Carreras, H. A., Orellana, L. and Pignata, M. L. (1997) Correlation between environmental conditions and foliar chemical parameters in Ligustrum lucidum Ait. Exposed to urban air pollutants. J. Environ. Manag., 49: 167-181.

Farquhar, G. D. and Sharkey, T. D. (1982) Stomatal conductance and photosynthesis. Ann. Rev. Plant Physiol., 33: 317-345.

Gej, B. and Gozlinski, H. (1983) Gas exchange and accumulation of mineral components in assimilatory organs of trees growing in urban conditions. Polish Ecological Studies, 9: 255-265.

Hirano, T., Kiyota, M. and Aiga, I. (1991) The effects of dust by covering and plugging stomata and by increasing leaf temperature on photosynthetic rate of plant leaves. J. Agric. Meteorol., 46: 215-222.

Hodge, S. J. and Boswell, R. (1993) A study of the relationship between site conditions and urban tree growth. J. Arboriculture, 19: 358-367.

Jim, C. Y. (1992) Tree-habitat relationships in urban Hong Kong. Environmental Conservation, 19: 209-218.

Kammerbauer, H., Ziegler-Jönes, A., Selinger, H., Römmelt, R., Knoppik, D. and Hock, B. (1987) Exposure of Norway spruce at the highway border: Effects on gas exchange and growth. Experientia, 43: 1124-1125.

Lambers, H., Chapin III, F. S. and Pons, T. L. (1998) Plant physiological ecology. 540 pp. Springer, New York.

Mansfield, T. A. and Freer-Smith, P. H. (1981) Effects of urban air pollution on plant growth. Biol. Rev., 56: 343-368.

Pandey, J. and Agrawal, M. (1994) Evaluation of air pollution phytotoxicity in a seasonally dry tropical urban environment using three woody perennials. New Phytol., 126: 53-61.

Statistical Bureau of the City of Fukuoka $(1995,1998)$ Statistical yearbook of city of Fukuoka. p. 13. City of Fukuoka, Fukuoka (in Japanese).

Takagi, M., Gyokusen, K. and Saito, A. (1996) Urban micro environment and photosynthesis of street trees. J. Jpn. Soc. Reveget. Tech., 22: 15-23.

Takagi, M., Gyokusen, K. and Saito, A. (1998) Increase in the $\mathrm{CO}_{2}$ exchange rate of leaves of Ilex rotunda with elevated atmospheric $\mathrm{CO}_{2}$ concentration in an urban canyon. Int. J. Biometeorol., 42: 16-21.

Treshow, M. and Anderson, F. K. (1989) Plant stress from air pollution. 283 pp. John Wiley \& Sons, New York.

von Caemmerer, S. and Farquhar, G. D. (1981) Some relationships between the biochemistry of photosynthesis and the gas exchange of leaves. Planta, 153: 376-387.

Whitlow, T. H., Bassuk, N. L. and Reichert, D. (1992) A 3-year study of water relations of urban street trees. J. Appl. Ecol., 29: 436-450.

Wolfenden, J. and Mansfield, T. A. (1991) Physiological disturbances in plants caused by air pollutants. Proc. Roy. Soc. Edinburgh, 97B: 117-138.

(Accepted 30 January 2002) 